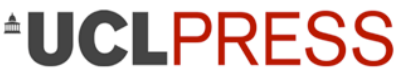

\section{The Journal of the Sylvia Townsend Warner Society}

\section{Innocence, Naivety, Directness: Children in Sylvia Townsend}

Warner's Fiction

Jan Montefiore ${ }^{1, *}$

How to cite: Montefiore, J. 'Innocence, Naivety, Directness: Children in Sylvia Townsend Warner's Fiction.' The Journal of the Sylvia Townsend Warner Society, 2019, 18(2), pp. 23-40. DOI: https://doi.org/10.14324/111.444.stw.2019.12

Published: 12 April 2019

\section{Peer Review:}

This article has been peer reviewed through the journal's standard double blind peer-review, where both the reviewers and authors are anonymised during review.

\section{Copyright:}

(C) 2019, Jan Montefiore. This is an Open Access article distributed under the terms of the Creative Commons Attribution License (CC-BY) 4.0 https://creativecommons.org/licenses/by/4.0/, which permits unrestricted use, distribution and reproduction in any medium, provided the original author and source are credited • DOI: https://doi.org/10.14324/111.444.stw.2019.12

\section{Open Access:}

The Journal of the Sylvia Townsend Warner Society is a peer-reviewed open access journal. 


\title{
Innocence, Naivety, Directness: Children in Sylvia Townsend Warner's Fiction
}

Jan Montefiore

\begin{abstract}
This essay argues that Warner's frequent portrayals of children in her mid-century fiction, particularly her short stories, are closely connected with her sharp critiques of bourgeois conventionality ('The Cold', 'Noah's Ark') and of fascism ('Apprentice', 'View Halloo'). Thanks to their unembarrassed clarity of perception and direct self-expression, Warner's children openly voice the aggression and/or heartless indifference shared by their (usually) politer elders. This dark vision is partly alleviated in Warner's later work by stories in which children's fresh perceptions allow them respond sensitively to the beauty of music, poetry, fur growing on a cat's nose or a wild garden.
\end{abstract}

Keywords Sylvia Townsend Warner; childhood; fascism; antiSemitism; innocence

Death and aggression are rarely far away when Sylvia Townsend Warner writes about children. My main focus here is on her short stories, but I begin with the short lives of Damian and Augusta Willoughby in Summer Will Show and the twin brothers Samuel and Julius Barnard in The Flint Anchor, both set in early Victorian England; all four are victims of severe infectious illnesses compounded by lethal medical interventions. The carefully brought up Damian and Augusta Willoughby die of smallpox, after being held over a lime kiln - to inhale its fumes as a cure for coughs which have lingered into July - by a workman who is infected with smallpox. The scene of their delirium during a heatwave, when their mother Sophia overhears them howling feverishly for water while their 
trained nurse allows them only wine or a warm soup, is unforgettable. ${ }^{1}$ The equally wretched Samuel Barnard catches measles, leading to agonising abscesses in his ears so that he screams when hot poultices are put on. Further medical horrors are not spared: 'Bleeding, cupping, leeches, strong purges, a lowering diet, everything that Dr Kitter could suggest was tried.' ${ }^{2}$ His brother Julius survives; but, too weak to apply himself satisfactorily to his Latin, he is bullied into a decline, dying in six months from consumption hastened on by his father's punishments of bread, water and isolation from his pious family.

These nineteenth-century children are the obedient and welltrained victims of piety and convention, medical and social. How, then, are they to be related to the conference theme 'Sylvia Townsend Warner and Modernism'? In fact, Warner's emphasis on the unnecessary cruelty of their deaths does more than point to the drawbacks of being born into privileged families which can afford the best doctors in a pre-scientific age; it amounts to a fierce repudiation of the improving deathbeds of pious children in evangelical books such as Mary Sherwood's The Fairchild Family (1818) or Maria Charlesworth's Ministering Children (1854). The outlook of Warner's historical novels is an emancipated modernity, sceptical of the Victorian virtue of filial obedience, well aware of humanity's capacity for hatred and cruelty at any age and implacably opposed to any form of pious orthodoxy. Her fictions attacked not only Christian piety (by the mid-twentieth century a fairly easy target) but the respectable conventionality of middle-class English people who want everything to be nice, whether these are cheery clergymen, bossy ladies of the manor or middle-class liberals keen on modern art and child psychology. And whereas the children in Summer Will Show and The Flint Anchor are brought up to be seen and not heard, the children in her short stories express themselves far more openly, their candid savagery sometimes startling respectable adults. One cannot imagine a Willoughby child, still less a Barnard, revelling in a tiger's ferocity like Malcolm in 'Noah's Ark', or furiously wishing its parents dead like Charlotte at the end of 'Total Loss'. And unlike the children in the historical novels who are almost always seen from outside, Warner's twentieth-century children quite often function as the narrative lens, sometimes for part of the story, like Charlotte in the first scene of 'Total Loss' or Johnnie in 'Two Children', sometimes for its entirety, as in 'Apprentice', the much lighter late story 'QWERTYUIOP' and 'The Inside-Out'.

To call Warner's fictional rendering of children unsentimental is to put things mildly, and not only because of these unrelenting 
scenes of children dying in pain and uncomforted. There is pretty little Lili complacently tormenting Polish children until she kills one in 'Apprentice', Venice in 'Noah's Ark' relishing wolves and their 'hideous howls', Kenneth in 'The Mothers' climbing up to kill fledglings, 'nice' English children persecuting their Jewish hostess in 'View Halloo', the dear little boy Roger in 'Time's Silvering Hand' delighting his elderly spinster relation with second-hand horror stories of the Blitz ('Once she tripped over something in the dark, and it was a head ... And another time she picked up a hand and it was holding a kettle, and the kettle hadn't a scratch on it') ${ }^{3}$ and the boy Tony in 'A Stranger with a Bag' with his grotesquely comic cold in the head, 'dancing like a ferret at the sight of his father's blood' after handing a sharpened carving knife to the passing stranger and demanding 'I want you to burder Dad ... Burder hib, burder hib!'4 Death reappears in the late 'Two Children', in which the older sister Bella is a greedy nagging coward who, unlike her tough little brother Johnnie, insists against the evidence that the drowned man cast up by last night's storm must be 'nothing but a seal'. ${ }^{5}$ Then there are the boys in the 'The Cold', briefly glimpsed through the adoring mother who avoids actually looking after them ('You couldn't really call them spoilt, they were just wartime, lacking the influence of a father about the house. Besides ... it would be too awful if they grew up like Neville's ghastly younger brother who would sit for hours stroking the cat' (MC 35: no wonder the maid leaves her job)) and the briefly glimpsed London children in 'The Fifth of November' with their 'chant ... like a hail of pebbles: "Guy, guy, hit him in the eye! Hang him on a lamp-post and never let him die!". ${ }^{6}$ It is a gallery of little horrors.

That said, children's aggression is not the whole story. Warner's later stories in particular vividly portray children experiencing the enchantments of language ('QWERTYUIOP'), of music ('Four Figures in a Room'), of poetry ('A Spirit Rises'), of the fur on a cat's nose, 'the mysterious smooth conflict between two currents of growth' ('Total Loss') and of untrodden wilderness ('The Inside-Out') - all differently moved by what Gillian Beer has admirably called Warner's responsiveness to 'the tumbling pleasures of the ordinary moment'. ${ }^{7}$ Warner's sensitive children have much in common with the familiar post-Romantic figure of the child as a spontaneous being, its fresh perceptions untainted by custom, as in the formerly well-known study by Peter Coveney. ${ }^{8}$ The six children in Virginia Woolf's The Waves belong in this tradition despite their stylised language, responding intensely to being bathed or watching insects among the currant bushes, as does 
Stephen in Joyce's A Portrait of the Artist, fascinated by language and by scenes whose full meaning he doesn't always grasp.

A related aspect of children which interests Warner is their naivety. She wrote that children 'have unembarrassed eyes', ${ }^{9}$ but they don't necessarily understand what they see. So Charlotte, a noticing but 'not a very deductive child' ( $S B$ 192), sees that her cat has a 'thirsty expression' ( $S B$ 189) but won't drink, and that her mother is uncomfortable chatting with a visitor and is 'laughing obligingly' (SB 191), without realising that these are ominous signs. Far more obtuse is Mary Barnard in The Flint Anchor when the narrative slips briefly into her heartless mind:

Only Mary noticed her father. The look she bent on him was grave and composed. She was thinking that he was unhappy. Papa was unhappy, as a day is rainy: it was a thing to accept, but not to reason over. For John Barnard's children were almost without compassion. Talk about God's will, dispensations, sorrows sent as trials of faith or moderate expressions of justly merited disapproval, and quite sincere attempts on John Barnard's part to live up to this sort of talk, had smothered it. So while aware that Papa was unhappy, it did not occur to Mary that the death of two sons and the desertion of another was anything special for Papa to be unhappy about. ${ }^{10}$

\section{The wartime stories}

Well before Mary Barnard, Warner had dissected what breeds about the heart of a sweet little girl in her wartime story 'Apprentice' (1943), though without the authorial intervention which, in The Flint Anchor, explains how the child became unfeeling. Told in free indirect narration, the story's focus is Lili, the child of a German brothel under the protection of the Nazi officer Major von Kraebeck in occupied Poland, who like Mary Barnard believes herself to be a 'sweet child' because adults have told her so. ${ }^{11}$ Lili watches Polish people going past her house with 'gramophones, mattresses, statues, cooking-pots' and even a chiming gold clock, and coming back with 'beetroots or cabbages', without realising that she is seeing the effects of famine until a servant collapses from hunger (GS 15). Warner knows that naivety is not the same as innocence; with a modernist's awareness that social identities are not innate but constructed, she shows the 
little girl growing into her fascist mind-set, making the Major roar with laughter at her description of the starved, yellow-faced, swollen-bellied Polish children - 'Boys and girls, they all look like monkey mothers' (GS 18) and going on to invent her sadistic game of 'feed the starving' (GS 17) by making them jump for food scraps held above them on a string.

Warner's children are usually more conventionally middle class than Lili, but the latter's acting out of Nazi cruelty is paralleled by apparently nice English children whose disquieting thoughts and actions are likewise shaped by adults whose values they have learnt to share. Unlike adults, they are direct, lacking the hypocrisy to appear kinder or nicer than they really are. Of the child who wrote of T. H. White 'I am not glad he died', she observes 'The writer was eight years old - an age when it is possible to say exactly what one means, neither more nor less.' ${ }^{12}$ Hence the alarming candour of Tony in 'A Stranger with a Bag', uncompromisingly announcing his murderous hatred for the ludicrous, self-pitying 'Dad' who blights the family's life. In other stories of middleclass families, Warner uses the unembarrassed directness of children to manifest nakedly the snobbery and selfishness of their family's class attitudes.

David James's essay on Warner's realism (2005) argues that by combining authorial self-erasure with irony, she answers the call for impersonal realism in Storm Jameson's 1937 essay 'Documents', which had argued that writers ought to keep their own feelings and opinions out of their work, aiming for a realism that says 'everything' through chosen telling details and incidents.

Warner re-envisioned the potential of realism and in doing so, redirected a high modernist commitment to the discursive mastery of form towards fiction's ability to engage with specific social issues of her time ... Her miniaturist fables reveal a recurrent activity of authorial obligation articulated through depersonalisation, while each enunciating their own idiosyncratically astringent manner of reporting atrocity. ${ }^{13}$

His prime example is naturally 'Apprentice', and he quotes the passage when Lili begins her deadly game: ${ }^{14}$

Yet to Lili it seemed very nice to feed the starving. It was exciting, it made one feel good. Before they came to Poland she had had a little dog, and she always enjoyed feeding it, throwing a biscuit 
and seeing him dash after it, holding a bone above his head while he begged and rolled his eyes. It occurred to her that she could feed the starving from her summer-house. She would feed children; no one could much object to that, for they would be Polish children only, all the Jews had been put away. (GS 17-18)

Warner is very acute on the mechanism of 'othering' as dehumanisation (seeing the children as animals gives Lili licence to tease them) and of the close relationship between cruelty and pious sentimentality. Lili considers that the boy who resists her bait and encourages other children to refrain is 'cruel, for he tried to prevent the poor hungry children from getting their crusts'. On the day she breaks him (literally, for he breaks his neck by leaping after the cinnamon bun she has dangled in his face), she is able to blame her victim: 'Poor boy! He should not have been so proud, so unpleasant ... It was not her fault that he had died so horribly of starvation' (GS 24). Sentimental to the last, Lili notices the 'poor bun still dangling' and eats it (perhaps a touch of authorial overkill here). David James argues that this story is peculiarly discomforting because of its narration through Lili's consciousness without overt commentary. This reading seems quite close to Warner's own praise of Jane Austen for creating odious characters by 'appearing to write without animus. "Give them enough rope," she seems to say, "and they will hang themselves." 15 Austen's narratives, however, do not confine themselves to the mind of a John Thorpe or a Mrs Norris, whereas in 'Apprentice', argues James:

one is encouraged to become a relatively abstracted co-observer lacking an authorial guiding hand ... [Warner's] readers are helpless to prevent the seed of Fascism from taking root in the girl, and helpless to prevent their own assumption of and implication in a Fascist perception of human life ... Warner's unnerving withdrawal from humane commentary reveals precisely how she renders impassive an exterior perceiver so as to intensify our attention to the inhumanity of events perceived. ${ }^{16}$

But I think David James overstates his case here. Unlike first-person narration, free indirect narrative does not invite identification, and the irony of 'Apprentice' is obvious from beginning to end. As Maud Ellmann writes in a recent brilliant psychoanalytic reading of this story, 'Warner implies that Lili's depravity is structural, not personal.'17 Far from leaving readers 'helplessly' implicated in the child's outlook, Warner's 
contemptuously deadpan narration holds up the willing 'apprentice' to cruelty, with her eyes like close-set 'flax blossoms' (GS 15), as the nasty little specimen of Nazi mentality she is. (A similar but lighter effect is created in the satirical story 'The Cold', another free indirect narrative which is focused through Mrs Ryder, the rector's wife; Warner's irony at the pious self-deceptions in her every sentence is merciless.) The effect Warner produces by inhabiting Lili's self-justifying cruelty is not dissimilar to the ironies of Browning's 'Porphyria's Lover' or 'My Last Duchess', in which the speakers are unaware they reveal their own murderous natures.

A Garland of Straw has two further stories featuring children. 'Noah's Ark' and 'Two Mothers' are complementary satiric antipastorals, each centred on a child's response to animals. In 'Noah's Ark', an orphaned brother and sister evacuated from London to the West Country make their well-meaning hostess Mrs Purefoy frightened and uncomfortable by their enthusiasm for exotic wild animals, ${ }^{18}$ which brightens up their otherwise 'cautious melancholy reserve' (GS 88). Their evident familiarity with the London Zoo, to which English lambs come a very poor second, inspires Malcolm to grow lyrical about his favourite tigress:

'She's very sweet-tempered really, and underneath she's a lovely lemon-colour. But when she gets in a temper you should just see her. She yowls and shakes the bars of her cage, and her hair stands out, and as for her claws ...'

'What dread hands,' murmured Venice. 'And what dread feet?' 'Yes, my dear, their claws must be dreadful.' (GS 87)

Malcolm and Venice are portrayed with complete sympathy for their shared world of animal wildness, freedom and poetry - for in addition to Blake, Venice quotes Shelley's 'Mask of Anarchy' ('Teacher said, Men of England, wherefore plough for the lords who lay ye low?' (GS 86)) and is later inspired by wolves to swing 'round and round with her eyes shut, and chanting: "When the wolf that nightly prowls/ Bays the moon with hideous howls. /Waa-oo! Waa-oo! Hideous howls!"' (GS 91). ${ }^{19}$ These conversations upset Mrs Purefoy and give her bad dreams, but her husband the shepherd, who finds lions and tigers 'a pleasant change' from his overfamiliar lambs, enjoys the menagerie, gives the children coloured chalks and 'commissioned works of art, such as Tigers pulling down an Elephant, or A Boa constrictor climbing a palm-tree after a Bear' (GS 88). His wife remains disconcerted by the children's 
passion for wild beasts, especially when they take literally her offer to invite the local Wolf Cubs to tea ('But what could we feed them on, Mrs Purefoy? They don't really like anything but meat' (GS 90)). But the joyous freedom of the children's imaginary world is shattered once Mrs Purefoy informs them, 'with an almost genuine benevolence', that 'Owing to the continuance of blitz bombing the authorities of the Plymouth Zoo have caused all the dangerous animals to be destroyed.' They are stoical enough not to weep that 'their Ark, so brightly painted, so gloriously companied, had foundered under them', leaving them to the blank desolation of the everyday. The final sentence informs us drily that they are soon 'drawing bombers and stoning water-rats like any other children about the place' (GS 92-3).

In 'Noah's Ark', the children's creative imagination is set against the conventional mealy-mouthed adult, almost in a straightforwardly post-Romantic way, although the children are better educated than the adult (who doesn't recognise the Blake quotation), while Venice's disturbing enthusiasm for the howls and smells of wolves (GS 91), without directly endorsing psychoanalytic theories of childhood, implies both sexuality and aggression. The children in 'The Mothers', by contrast, are pupils at a village elementary school, as mean-minded as their parents. The schoolmistress Mrs Pitcher, resented for her 'superior' fastidiousness and rebuked by the vicar for upsetting her classes with stories of 'German concentration camps and the persecution of the Jews' (GS 105), has two grown sons in the army, one of whom disappears during the fall of Singapore. She 'hates springtime' because it means teaching nature study and trying to 'prevent the children from stealing birds' eggs, cutting the wings off fledglings, and throwing stones at valuable pedigree calves' (GS 107). But when swallows start building in the school porch, she conscientiously gives the school an edifying lecture on how swallows 'come to England in order to have their little ones, flying all the way from Africa, led by the most wonderful instinct (and more fools they) ... And in autumn ... they gather their young ones and fly back to Africa (if they have survived to do it)', how they usefully catch flies and have had 'many beautiful poems written about them'. To this sermon, the stolid children respond: 'Africa's where the fighting is' and 'Your other son's in Africa, isn't he?' (GS 107-8).

For all Mrs Pitcher's unspoken sarcasms while preaching of the loveliness of swallows, she becomes obsessed with guarding their nest. A few weeks later, surprised to see the boy Kenneth, 'a negligible creature, pale and dull and born to be bullied', swarming up a rope to 
get at the baby birds, she pulls him off. 'Why, it's cruel! Think of the poor mother!'

Scrabbling up handfuls of pebbles, he began to stone the nest.

'I hate them! I hate them! I wish I had a gun, I'd shoot the lot. No, I wouldn't!

I'd catch them and wring their heads off.'

The boy's mother hears his voice and rushes up to defend him. He is not grateful, shouting 'I hate you all!' and running into the rainy street (GS 110).

Avoiding any overt commentary, the story shows the teacher and her pupil separately projecting their own feelings onto the fledglings. Mrs Pitcher's intense protectiveness betrays displaced anxiety for her son in Africa ('Why don't you think about your own flesh and blood for a change, instead of those bloody birds?' gripes her husband (GS 107)), while the boy's rage manifests his fury at being bottom of the heap. (Given a machine gun instead of pebbles, one can quite easily see Kenneth carrying out a massacre on his village school.) His outburst both concentrates the petty malice of village society and disrupts it, leaving his mother and teacher equally dismayed. It is not suggested that his attack on the baby birds is caused by the war; as in 'Noah's Ark', cruelty to animals is apparently the accepted norm for country children, hence the mothers' resentment of the schoolteacher's 'nonsense about birds' nesting' (GS 105) when she tries to discourage them from stealing eggs. I do not know how far Warner's cynicism was historically justified, but it has literary corroboration in George Orwell's Coming Up for Air (1938) in which the narrator-hero George Bowling reminisces lyrically about stoning birds and torturing toads to death during his rural boyhood. 20

The post-war 'View Halloo', showing the dark side of middleclass English families, deals much more grimly than 'Noah's Ark' with children's violent fantasies, and almost as shockingly as 'Apprentice' with respectable people's self-justifying spite against those perceived as 'other'. It is set in a post-war holiday house in Wales, brutally modern and bleak with plate-glass windows and high ceiling lights, where a childless Jewish couple are taking a just-affordable holiday by sharing the house with paying guests, whom they found by advertising in the New Statesman. Here the narrative lens is not a child but an innocent adult, the kind and practical Antoinette Kauffman, who is puzzled to find by the house telephone a drawing of 'a woman's head and shoulders 
with a jagged line transfixing the head from above. Underneath was written Lightning Striking Mrs Lawther' (MC 41). An ensuing conversation about ghost stories draws from the boy Francis Hepburn the tale of 'a horrible woman who wore fur':

'She wore fur. And ear-rings. And a great deal of beastly expensive scent. And stockings. And she thought everyone bowed down to her.'

'I see. A Left story. Do go on, Francis!' (MC 43)

(The comment is spot on; as I have argued elsewhere, the figure of the rich woman punished for personifying bourgeois privilege is an all-toofamiliar trope of 1930s left-wing writing. ${ }^{21}$ ) The tale continues, with the woman's fur coat attracting an amorous bear who chases her up a tree; she falls and is drowned in a waterfall where her ghost remains, "howling with cold, and ever since people have heard her teeth chattering all night' (MC 43). Francis's lively imagination and eloquence may seem as delightful as Malcolm and Venice praising their fierce imagined animals in 'Noah's Ark', until Antoinette hears the children chanting 'Mad Bulls tossing Mrs Lawther!', and realises what they're up to.

'You can't get out of the magic circle till it's all finished! Now Judith, give me three of your hairs. And pull them out properly, mind, so that it hurts. No cheating!'

Judith giggled, and exclaimed Ow! Then a match was struck.

'Now! All together! Hateful Mrs Lawther! Hateful Mrs Lawther! Mad Bulls tossing Hateful Mrs Lawther!'

The stamping and the chanting ended as efficiently as a drill, and were followed by a religious silence .... . And was this how uninhibited children played?

Apparently Judith was less uninhibited than the Hepburns, for now she said in an infidel, dissatisfied voice: 'But I still don't understand why we have to call her Mrs Lawther? Why can't we just say Mrs —_

'Ssh! We must never say it. That's another part of the magic. Besides, Lawther is just what she's like. Law-ther. Law-ther. All dragged-out and slimy.'

'My turn now,' said Francis. 'I've thought of a beauty. Red Rats eating Mrs Lawther.' (MC 47-8)

He exits for a red pencil, sees her, stops dead and nearly screams: 
All encounters with children are touched with social embarrassment. Antoinette was sorry she had overheard this private performance, it had shocked her. It seemed false and oldfashioned, as though these children were playing at being the children in a children's book of an earlier generation. A day or so before, when Lionel Hepburn were explaining the atomic bomb in scornful popular language, William and Francis were not only able to understand him, but alone among his listeners were genuinely and impersonally interested. Then she had said to herself that after all the future would be in the hands of children brought up to face the truth with tranquillity. Yet here they were playing at sympathetic magic and secret societies like a little Ku Klux Klan. (MC 48)

Antoinette has not grasped the full implications of the game; it's her husband Leonard who realises that Lightning Striking Mrs Lawther is meant for her. She protects him from knowing just how far the game has gone: 'And what was it, after all, to make an outcry about? What was one Jew more or less among the millions, the millions?' (MC 51). She is frightened for the obvious un-Englishness which makes Leonard vulnerable: 'It was his proudest, vainest boast that he was English, and free, in a free country ... How could she get him away in time? And where?' (MC 52).

Unlike Lili, the Hepburn boys in 'View Halloo' are educated and talented (Francis' drawing has merit, his spiteful ghost story is vigorous and original), the offspring of progressive New Statesman readers who believe in children being independent and uninhibited: 'God forbid they should become enslaved to regular habits!' (MC 45). Antoinette is probably right to tell her husband that the lightning zigzag in Francis' drawing is not consciously intended as 'a Blackshirt thing' (MC 51), and the children's 'Ku Klux Klan' game will not lead to an actual pogrom. But just as Lili's pleasure in teasing her hungry victims condenses the cruelty of fascism, the children's fantasy reveals the selfrighteous intolerance of their respectable middle-class English families who, as Antoinette knows and her husband doesn't, will never accept a Jew as 'one of us'. Because 'View Halloo' is seen, so to speak, from the fox's point of view, Warner makes the children and their parents seem both impermeable and invincible. (It's not hard, though, to guess that the game probably started from Francis Hepburn's resentment of Antoinette, so much more glamorous in her loving husband's extravagant gifts of 'the marmot coat, the pearls, the black-marketed 
eau-de-Cologne' (MC 44), than his own rock-climbing mother who leaves her children to their own devices. Doubtless one brother said 'Isn't she horrible?', and the pair started inventing punishments for her, calling her 'Mrs Lawther' so that the grown-ups wouldn't suspect anything, and they brought in little Judith Tupman as junior accomplice/audience.) These children are in their way as hauntingly vile as Lili in 'Apprentice'.

\section{Pleasures of the senses}

It is a relief to turn to the later stories, where Warner is interested not in children's aggression but in the freshness of their response to the world. (Tony in 'A Stranger with a Bag' is an obvious exception; but then his world appears to be bounded by his father's decaying, chilly, rat-ridden home, abandoned by his mother and with nothing to eat, not even the family's pet rabbits: 'We hab eaten theb. We ate old Roger yesterday' ( $S B$ 17).) Where these stories include a child's point of view, their language is far from childish, as when Colin and Stella in 'The Inside-Out' enter an overgrown garden: 'Everything was matted, entangled, overgrown, and intensely still. Some plumes of pampas grass wagged in the light breeze. They seemed be the only living thing there.'22

Warner wrote two moving stories about the experiences of children encountering art for the first time. Here the keynote is not aggression, but its more benign relation: sorrow. 'A Spirit Rises' (1961) begins with a conversation between an old woman and one of her father's former pupils, and relates the former's childhood memory of her father reading Elizabeth Barrett Browning's 'The Swan's Nest' while he held her before him on his rocking horse during a rainy summer afternoon.

She relaxed, abandoning her weight to the hard body behind her, leaving her legs to dangle, rubbing her head against her father's shoulder ... Just as the rocking horse kept measure, just as the rain fell in order to be silver, the voice went on in order to be poetry. It was familiar, and made itself unknown. Lulled and held and enchanted, happier than she had ever been before, she knew for certain that presently she was going to weep; but to weep as she had never wept before, to weep in acquiescence and delight and participation in a whole, as the rain fell in acquiescence to the 
grey sky, as the ferns on the bank spread out their fronds under the rain. She knew, too, that the rocking horse was bearing them towards a sad ending: that Ellie would die, or the knight be killed before he could be shown the swan's nest. But that was not why she would weep. (SR 156)

What the child responds to is the enchantment of melancholy poetry whose sadness encompasses and illuminates her world (and more subliminally, to the enchantment of eroticism as she sits against her father's 'hard body', rhythmically rocking). That intensity reappears again in 'Four Figures in a Room: A Distant Figure' (1973) whose title misleadingly suggests a painting. Two sisters, both violinists, are rehearsing a new composition in the intervals of discussing how to deal with their awkward old father who is now a hermit, and they are overheard by a little boy drawing a picture under their grand piano. Their prosaic conversation about the old man's obstinacy and their technical difficulties ('I don't know how I'm going to get a mute on in the time') is interrupted by the entrance of the composer, nicknamed by them 'MacRabbit', who silently resents them as 'professional circus horses, pillars of the Establishment ... worldly harpies' and argues crossly with them how to perform his work (MLV 158-60). The one person aware of the beauty being created is the little boy under the piano chalking in his picture of an alligator, waiting eagerly for the finale of 'Dialogue for Two Violins'. The composer knows it as his 'coda with its swaying five-beat ground bass'; the boy hears it, ecstatically, as an all-pervading sorrow:

The squeal hung on the air, brightened like a soap bubble, thinned, turned downward like a sigh, and was gone. Beneath it the muted voice had set out on its ghostly wandering. He felt his throat stiffen, ice form on his skin. It was the voice of something eternally lonely and destitute and blind. It probed his flesh. Tears streamed down his face as he wept for joy. (MLV 160)

The child's moment of ecstasy doesn't end the story. The composer notices him listening and is pleased, but there's no meeting of minds; the child sees him looking 'savage and anxious, as all grown-up faces are' (MLV 161). The story breaks off there, having accomplished a transcendent moment created by all-too-humanly flawed, limited and slightly frightening adults. The implication is that, as in Blake's Proverb of Hell, 'Eternity is in love with the productions of Time.' 
The children in these lyrical stories are exceptional in their sensibility (after all, one of them is Warner's only slightly fictionalised younger self) and also unusual in being introduced by the adults around them to art which is beautiful, demanding and tragic. The children in 'The Inside-Out' and 'Total Loss' are more ordinary and yet their perceptions are crucial to the narratives. In 'The Inside-Out' (1972), a family moves into a grey urban semi-detached house romantically named 'Ullapool', where 'a mad old lady had ended her solitary days' ( $M L V$ 20). This sounds sinister; but to the exploring children, who have till now known only public parks, the neglected garden is full of mystery and possibility. It is enclosed by trees and curtains of bindweed inside a spiked iron fence, where 'you couldn't get out: nobody could get in' ( $M L V$ 21), secret and yet open to the sky, which gives the brother an 'inside-out' feeling. The children's enchantment with the romance of the wild terrain and what seems endless jungle, because they have to keep going round brambles and bushes, is intensified when, through a thin place in the bindweed, they see the repellent neighbouring garden of the next-door house 'Sorrento', whose hens in a cage and 'rows and rows of Brussels sprouts, exactly aligned' ( $M L V$ 23) leave them feeling thoroughly superior in their possession of their wilderness. Not for long, however; lying on the bough of a tree is a watchful older boy from next door, 'as reposefully dangerous as a panther' ( $M L V$ 23). Thinking like property-owners already, they sneer at him and try to dismiss him for trespassing but his hostility drives them indoors. The focus in the final paragraph switches to their dispossessed enemy who can no longer escape from the bleak rigidity of his home with its dismal rows of Brussels sprouts:

The boy stared down into the lost paradise, the succouring shelter from which he was driven out. The bough began to quiver with the vehemence of his dry sobbing. Tomorrow he would buy a slingshot. (MLV 24)

This is another of what David James calls Warner's 'miniaturised fables' of wider social conflict, this time enacting the process of colonisation. The small, overgrown urban garden appears to the delighted newcomers like the garden 'twenty by fifteen yards' recalled in Warner's autobiographical Scenes of Childhood, which seemed 'as wide as America'. ${ }^{23}$ The new children think of themselves as conquistadors taking possession of an unpeopled wilderness, planning to tame it by creating a 'bower of roses' and growing lilies in the abandoned the 
bathtub 'like the water-garden at Worple'. For them, the trespasser from next door is the serpent, or at least a dangerous panther. To him, they are invaders of his refuge, exiling him from the wild paradise he will never possess again, however he attacks them. The fable doesn't take sides between the boy who has loved the sheltering wilderness and the newcomers who will cultivate it; nor does it say which is the victim: the dispossessed outlaw or the children he plans to attack.

Shifts of perspective are also crucial to the story 'Total Loss', which begins with the child Charlotte and her pleasure in her old cat Moodie. For Charlotte and her over-conscientious mother Meg, love of the cat brings out their best qualities. Charlotte delights in Moodie's body, the fur on his nose, his warmth and softness, talking to him and looking after him as well as she knows how. The duty-ridden Meg softens into liveliness and affection when she recalls his behaviour; thinking poorly of their new little garden she remembers that Moodie 'shared her opinion ... he used it to scratch in, but for any serious haunting went to Mopson's Garage where he and the neighbouring cats clubbed among the derelict cars' ( $S B$ 199). Most of the story is taken up with the misery of Meg, who, after getting her daughter out of the way, waits alone for the vet to come and put the sick cat to sleep in restless pain and guilt, her real affection for the cat almost muffled by the good reasons for tidying him away: 'Moodie would be spared inevitable suffering, Charlotte protected from a possibly quite serious trauma, Alan undisturbed in his work' (SB 192-3). Meg does her best for everyone, including her gruff New Statesman-reader husband Alan (a journal Warner seems to have disliked), and when the vet finally arrives she goes to her room and tries not to think about what's going on: 'she looked out at the tossing trees and remembered that everyone must die' (SB 193-4). Because Meg is resolutely prosaic, the story resists the pathetic fallacy, rain and a violent thunderstorm on the summer day when a beloved pet is put to death appearing as simple coincidence. Charlotte's late return brings Meg punishment, when the child learns that not only is her beloved cat dead but that there can be no funeral because the vet has taken away Moodie's corpse:

After Charlotte, declaring she would never forgive them, never, that they were liars and murderers, that she hated them and hoped they would soon be burned to ashes themselves had somehow been got to bed, they sat down, exhausted, not looking at each other.

'That damned cat!' 
As though Alan's words had unloosed it, a wailing cry came from overhead.

'O Moodie, Moodie, Moodie!

'O Moodie, Moodie, Moodie!' (SB 200)

The dual focus here is brilliant, with its containment of Charlotte's grief and rage by the long and complex time clause governed by the verb 'had somehow been got to bed' intimating that the adults are relieved but guilty ('not looking at each other'). And after the long tension of the story, the simplicity of Charlotte's wail of sorrow, heard by her father as an irritant, expresses the full desolation which overwhelms her mother too, as she, 'completing his exasperation' ( $S B$ 200), joins in the lament. In this story at least, Warner makes the child her touchstone of feeling.

\section{Notes}

1 Sylvia Townsend Warner, Summer Will Show (London: Chatto \& Windus, 1936), p. 64-5.

2 Sylvia Townsend Warner, The Flint Anchor (London: Chatto \& Windus, 1954), p. 36.

3 Sylvia Townsend Warner, The Museum of Cheats (London: Chatto \& Windus, 1947), pp. 24-5. Subsequent references in the text are abbreviated to $M C$.

4 Sylvia Townsend Warner, A Stranger with a Bag (London: Chatto \& Windus, 1966), pp. 27,18 . Subsequent references in the text are abbreviated to $S B$.

5 Sylvia Townsend Warner, The Innocent and the Guilty (London: Chatto \& Windus, 1971), pp. 31-2.

6 Sylvia Townsend Warner, A Spirit Rises (London: Chatto \& Windus, 1962), p. 42. Subsequent references in the text are abbreviated to $S R$.

7 Gillian Beer, 'Sylvia Townsend Warner: "The Centrifugal Kick", in M. Joannou (ed.), Women Writers of the 1930s: Gender, Power, Resistance (Edinburgh: Edinburgh University Press, 1999), p. 85.

8 Peter Coveney, The Image of Childhood (Harmondsworth: Penguin, 1967).

9 Sylvia Townsend Warner, T. H. White (London: Chatto \& Windus, Jonathan Cape, 1964), p. 316.

10 Warner, The Flint Anchor, p. 39.
11 Sylvia Townsend Warner, A Garland of Straw (London: Chatto \& Windus, 1943), p. 14. Subsequent references in the text are abbreviated to $G S$.

12 Warner, T. H. White, p. 318.

13 David James, 'Realism, Late Modernist Abstraction, and Sylvia Townsend Warner's Fictions of Impersonality', Modernism/Modernity 12.1 (2005), pp. 111-31 (pp. 114-15).

14 James, 'Realism', p. 116.

15 Sylvia Townsend Warner, 'Introduction' to Northanger Abbey (1971), in With the Hunted: Selected Writings of Sylvia Townsend Warner, ed. Peter Tolhurst (Norwich: Black Dog Books, 2012), p. 246.

16 James, 'Realism', p. 117.

17 Maud Ellmann, 'Vaccies Go Home: Evacuation, Psychoanalysis and Fiction in World War II Britain', Oxford Literary Review 38.2 (2016), p. 250.

18 Warner doesn't actually say that Malcolm and Venice are orphans, but this is strongly suggested by the lady of the manor reassuring Mrs Purefoy that at least their mother isn't coming with them 'to unsettle them' (GS 85), by the telling lack of any mention of letters to or from their parents and by Mrs Purefoy's perception that 'wild beasts were meat and drink, home and mother to those poor dear children' (GS 89). 
19 Venice is quoting 'The Thieves', a song collected in the songbooks The Myrtle and the Vine (1800), The Skylark (1800) and The Edinburgh Musical Miscellany (1805) - presumably thanks to her enlightened 'Teacher'.

20 George Orwell, Coming Up for Air (1938; Harmondsworth: Penguin, 1981), pp. 64, 68.

21 Janet Montefiore, Men and Women Writers of the 1930s: The Dangerous Flood of History (London: Routledge 1996), pp. 94-105.

22 Sylvia Townsend Warner, The Music at Long Verney, ed. Michael Steinman (London: Harvill Press, 2001), p. 20. Subsequent references in the text are abbreviated to $M L V$.

23 Sylvia Townsend Warner, Scenes of Childhood and Other Stories (London: Chatto \& Windus, 1981), p. 59.

\section{Bibliography}

Beer, Gillian. 'Sylvia Townsend Warner: "The Centrifugal Kick", in Maroula Joannou (ed.), Women Writers of the 1930s: Gender, Power, Resistance (Edinburgh: Edinburgh University Press, 1999), pp. 76-86.

Coveney, Peter. The Image of Childhood (Harmondsworth: Penguin, 1967).

Ellmann, Maud. 'Vaccies Go Home: Evacuation, Psychoanalysis and Fiction in World War II Britain', Oxford Literary Review 38 (2016), pp. 240-61.

James, David. 'Realism, Late Modernist Abstraction, and Sylvia Townsend Warner's Fictions of Impersonality', Modernism/Modernity 12.1 (2005), pp. 111-31.

Montefiore, Janet. Men and Women Writers of the 1930s: The Dangerous Flood of History (London: Routledge, 1996).

Orwell, George. Coming Up for Air (1938; Harmondsworth: Penguin, 1981).

Warner, Sylvia Townsend. Summer Will Show (London: Chatto \& Windus, 1936).

Warner, Sylvia Townsend. A Garland of Straw (London: Chatto \& Windus, 1943).

Warner, Sylvia Townsend. The Museum of Cheats (London: Chatto \& Windus, 1947).

Warner, Sylvia Townsend. The Flint Anchor (London: Chatto \& Windus, 1954).

Warner, Sylvia Townsend. A Spirit Rises (London: Chatto \& Windus, 1962).

Warner, Sylvia Townsend. T. H. White (London: Chatto \& Windus, Jonathan Cape, 1964). 
Warner, Sylvia Townsend. A Stranger with a Bag (London: Chatto \& Windus, 1966).

Warner, Sylvia Townsend. The Innocent and the Guilty (London: Chatto \& Windus, 1971).

Warner, Sylvia Townsend. Scenes of Childhood and Other Stories (London: Chatto \& Windus, 1981).

Warner, Sylvia Townsend. The Music at Long Verney, ed. Michael Steinmann (London: Harvill Press, 2001).

Warner, Sylvia Townsend. With the Hunted: Selected Writings, ed. Peter Tolhurst (Norwich: Black Dog Books, 2012).

\section{Note on contributor}

Jan Montefiore is Professor Emerita of the University of Kent, where she taught English Literature and Women's Studies from 1978. Her books include Feminism and Poetry (1987, 1992, 2004), Men and Women Writers of the 1930s (1996), Arguments of Heart and Mind (2002) - all of which contain substantial discussion of Sylvia Townsend Warner's writings - and Rudyard Kipling (2007); in 2016 she published Shaping Spirits 1948-1966, a memoir in sonnets. She is also a long-standing contributor to The Journal of the Sylvia Townsend Warner Society. 